\title{
Amaurosis fugax
}

\section{MUDr. Helena Štrofová}

Vidente Vinohrady s.r.o. - soukromá oční ambulance, Praha

Amaurosis fugax je přechodná ztráta zraku, většinou monokulární, která trvá několik minut, výjimkou není ani 1 až 2 hodiny. Zrakové funkce se poté plně obnoví. Bývá způsobena přechodnou ischemií či cévní insuficiencí sítnice či zrakového nervu emboly z karotického řečiště či některou z jeho větví. Nutná je spolupráce oftalmologa, neurologa a internisty.

Klíčová slova: amaurosis fugax, oční a neurologické vyšetření, elektrokardiografie, echokardiografie, ultrasonografie karotid.

\section{Amaurosis fugax}

Amaurosis fugax is a transitory monocular visual loss, mostly monocular, which takes a few minutes, is no exception 1-2 hours. Visual functions are then fully restored. Usually amaurosis fugax is caused by transient ischemia or vascular insufficiency of the retina or optic nerve emboli from the carotid vessels or one of its branches. The cooperation of ophthalmologist, neurologist and internist is particularly needed.

Key words: amaurosis fugax, ocular and neurological examination, electrocardiography, ultrasound of heart and carotid arteries.

\section{Úvod}

Amaurosis fugax je prechodná porucha zraku (většinou jednostranná, vzácně binokulární) a je to hlavní subjektivní príznak oběhové nedostatečnosti karotického řečiště. Vyskytuje se u cca 40-50\% okluzí a závažných stenóz vnitřních krkavic (častěji u neúplných uzávěrů). Porucha zraku vzniká náhle, bez bolesti, bez aury i bez průvodních príznaků. Trvá od 2 do 10 minut, ale někdy i hodinu či dvě. Hloubka postižení je také různá - někdy je zachován světlocit či pohyb pred okem, jindy jde o skutečnou amaurózu. Odezní stejně rychle, jako vznikla. Někdy ji pacienti líči jako zatahující se oponu, jiní ji popisují jako rozpadající se televizní obraz. Frekvence atak je také různá, od 2 za týden či měsíc až po 10 za den. Častěji postihuje muže, nejčastěji kolem 5.-6. decenia (1, 2). Pacienty s amaurosis fugax Ize zhruba rozdělit do skupiny "mladých" (do 40 až 50 let) a "starých" (nad 40-50 let). U starších pacientů bývají př́ičinou amaurosis fugax obvykle ischemické prričiny, zatímco u mladších migréna atd. Ale v obou skupinách bychom měly vyloučit strukturální poškození oka a mozku. Přechodná ztráta zraku u dětí je méně častá než u dospělých, děti mívají častěji benigní pưvod. Mezi prričiny dočasné ztráty zraku u dětí patří migréna a epileptický záchvat (1).

Vzácněji je porucha zraku provázena druhostranným přechodným defektem motorickým či senzitivním, oslabením končetin nebo parestéziemi, někdy i dysartrií a přechodnou afazií při lézi dominantní hemisféry. Bývají príznakem nestabilní stenózy a. carotis interna.

Již zmíněné neurologické a oční příznaky (poruchy čití, hybnosti, afázie, poruchy zraku), které trvají do 24 hodin a bez následků odezní - se označují jako TIA - tranzitorní ischemická ataka. Vše nad 24 hodin je označováno jako ictus.

\section{Historie}

Na počátku 18. století pojem amaurosis fugax pouze odkazoval na ztrátu zraku. Kolem roku 1830 znamenal termín přechodnou slepotu, bez specifikace laterality nebo etiologie. Na počátku
19. století termín "přechodná monokulární slepota" byl často používán jako amaurosis fugax. $\checkmark$ posledních deseti letech amauróza fugax byla definována jako přechodná monokulární ztráta zraku, obvykle cévního původu. Amauróza po-

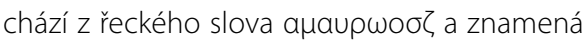
slepotu, fugax z řeckého slova puyax prchavý, to společně znamená: "prchavé oslepnutí" (3).

\section{Etiologie}

Asi $70 \%$ je způsobeno uzávěrem nebo výraznou nestabilní stenózou snižující průtok vnitřní karotidou o 70-80\%. Přímou příčinou jsou bud’ následné hemodynamické změny v retinálním řečišti bez kolaterál, nebo mikroembolizace $z$ arodovaných sklerotických plátů, popř. embolie tzv. Hollenhorstovými pláty - shluky trombocytů, fibrinu a cholesterolu, viditelné jako žlutavé krystalky na bifurkaci sítnicových artérií.

Vzácněji jde o mikroembolizaci u syndromu aortálního oblouku, při srdečních chlopňových vadách, fibrilacích síní i zvýšené viskozitě (hyperkoagulaci) a srážení krve (1, 2, 4, 5).

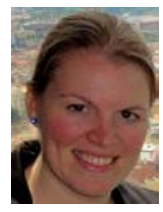


Tab. 1. Klinický obraz a nejčastější př́činy prechodné ztráty zraku

\begin{tabular}{|l|l|l|l|l|}
\hline Etiologie & Trvání & Klinický obraz ztráty zraku & Přidružené nálezy \\
\hline Papiloedém & sekundy & binokulární, zamlžení & bolest hlavy, tinitus, diplopie & venózní stáza, arteriální hypoperfuze \\
\hline $\begin{array}{l}\text { Vertebrobazilární } \\
\text { insuficience (VB) }\end{array}$ & sekundy až minuty & binokulární, koncentrická nebo zamlžení & vertigo, diplopie \\
\hline Retinální emboly & $3-5$ minut & monokulární, kvadrantická či altitudinální & Hollenhorstovy pláty \\
\hline Retinální migréna & $10-20$ minut & monokulární (kvadrantická, altitudinální) & $\begin{array}{l}\text { bolest hlavy, rodinná } \\
\text { anamnéza }\end{array}$ & embolie \\
\hline Migréna s aurou & $10-60$ minut & binokulární, hemianoptická, scintilace & po auře obvykle bolesti hlavy & šíření kortikální deprese \\
\hline
\end{tabular}

4. Bacigulapi M. Amaurosis Fugax: Clinical Comparison, The Internet Journal of Allied Health Sciences and Practice, 2006, 4(2). http://ijahsp.nova.edu

Obr. 1. Městnavá papila zrakového nervu-papila neostře ohraničená, lehce nad niveau

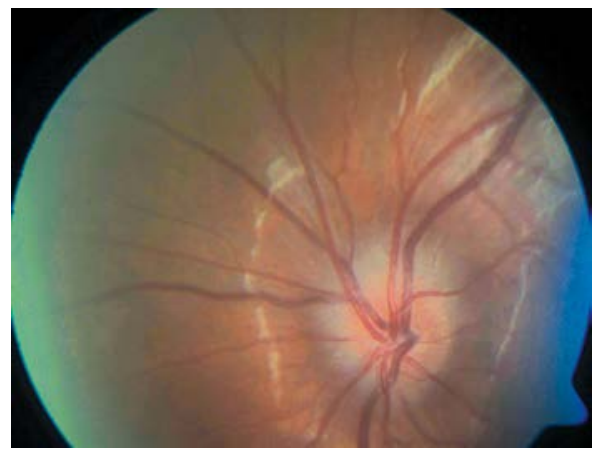

Obr. 2. 2a) Drúzy papily zrakového nervu - barevná fotografie - papila neostře ohraničená, okaje papily hrbolaté - drúzy; 2b) sonografie - v oblasti papily ZN vysoce echogenní ložisko, odpovídající klinickému nálezu drúzy

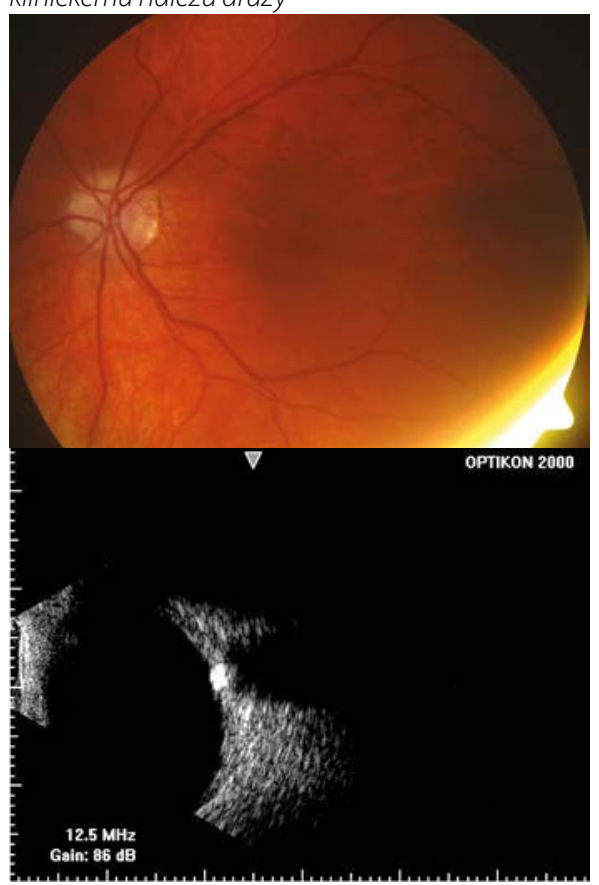

\section{Diagnóza}

Nezbytná je pečlivá ANAMNÉZA. Ptáme se, zda je porucha zraku monokulární nebo binokulární a jak dlouho ztráta zraku trvala, nebot’ doba trvání ztráty zraku poskytuje cenné informace o etiologii. Dále se ptáme, zda pacient již měl v minulosti projevy amaurosis fugax či TIA. Dotazujeme se v osobní anamnéze na onemocnění srdce a další kardiovaskulární rizikové faktory - jako je hypertenze, hyperlipidemie, diabetes mellitus, srdeční onemocnění, abúzus kouření, alkoholu, kokainu, v rodinné anamnéze na cévní mozkové príhody, ... Zaměřujeme se i na uživání perorální antikoncepce $(1,2,4)$ (tabulka 1 - Klinický obraz a nejčastější přičiny přechodné ztráty zraku, tabulka 2 - Klíčové otázky u pacientů s přechodnou poruchou zraku). Kompletní neurologické a oftalmologické vyšetření jsou dưležitá, protože abnormální nálezy by mohly pomoci lokalizovat lézi a zjistit etiologii. OČNÍ VYŠETŘENÍ - včetně vyšetření očního pozadía vyšetření zorného pole. Oční lékař hledá embolus. Pokud je oční nález fyziologický, bez zjištěné oční př́ičiny, doporuČujeme vyšetření u internisty a neurologa $(1,2)$. NEUROLOGICKÉ VYŠETŘENÍ - vč. elektroencefalografie (EEG). INTERNÍ VYŠETŘENÍ - včetně vyšetření krve (krevní obraz, diferenciální rozpočet leukocytů, glykemie nalačno a lipidový profil - k vyloučení polycytemie, trombocytózy, cukrovky, hyperlipidémie). $K$ vyloučení obrovskobuněčné arteriitidy vyšetříme sedimentaci erytrocytů. Dále poslech karotid (karotický šelest, slyšitelný nad bifurkací u stenóz snižujících průtok aspoň o 50\%) a srdce, elektrokardiografie (EKG), echokardiografie (ECHO) a ultrasonografie karotid. Sonografie je neinvazivní vyšetření, které měři míru extrakraniální stenózy tepny a poskytne důležité informace o konfiguraci cévní stěny a morfologii aterosklerotického plátu. Magnetická rezonance - MRI - krku je další neinvazivní měření průměru karotidy. Nicméně, MRI má tendenci přeceňovat stupeň stenózy, avšak toto omezení můžeme odstranit použitím kontrastu. S vysokým rozlišením počítačové tomografie - CT - je možné také přesné posouzení stupně stenózy karotidy a hodnocení složení aterosklerotických plátů. Riziko cévní mozkové príhody závisí nejen na stupni stenózy, ale také na vlastnostech aterosklerotického plátu (1).

Diferenciální diagnóza - Přechodná porucha zraku může být způsobena těmito vadami:

Oční choroby - vteřinové obnubilace při městnavé papile - zduření papily zrakového nervu, je způsobeno vzestupem nitrolebního
Tab. 2. Klíčové otázky u pacientů s prechodnou poruchou zraku

- Věk pacienta?

- Jak často se príznaky objevují?

- Jak rychle príznaky vznikají?

- Jak dlouho přiznaky trvají?

- Jsou príznaky na jednom či obou očích?

- Popište zrakové poruchy - pozitivní či negativní fenomény

- Je prítomna bolest v souvislosti se zrakovou poruchou?

- Změní se príźznaky zamrkáním či promnutím oka?

- Zhorší se zrakové príznaky při cvičení?

- Zhorší se problémy při pohybu očí?

- Je př́tomna horečka, hubnutí, bolesti príižvýkání?

- Bývá prítomna nauzea?

- Bolest hlavy v anamnéze?

4. Bacigulapi M.: Amaurosis Fugax: Clinical Comparison, The Internet Journal of Allied Health Sciences and Practice, 2006, 4(2). http://ijahsp.nova.edu

tlaku (tumory, krvácení mozku, prípadně infekce). Obvykle je porucha oboustranná, trvá několik sekund. Také musíme vyloučit drúzy papily zrakového nervu sonograficky (obrázek 1, 2).

Uhthoffưv fenomén při parciální atrofii zrakového nervu po retrobulbární neuritidě. Jedná se o zhoršení neurologických symptomů včetně zraku, u pacientů s roztroušenou sklerózou po cvičení nebo s rostoucí tělesnou teplotou. To může mít vliv na jedno nebo obě oči, trvá několik sekund až minut a odráží dríve existující demyelinizaci optického nervu.

Scintilujícískotom při acefalgické formě oftalmické migrény - trvá 10-60 minut. Migrenózní poruchy zraku jsou také běžné u starších pacientů. Zraková aura se vyskytuje u 1-2\% starších pacientů a v 58\% není aura spojena s bolestí hlavy.

Obrovskobuněčná arteriitida - pacienti bývají ve věku nad 50 let, mívají bolest na spánku, klaudikace při žvýkání, kousání nebo svalové bolesti. Přechodná ztráta zraku může předcházet ischemickou neuropatii optiku či centrální okluzi retinální arterie v důsledku zánětlivého uzávěru očních a ciliárních větví.

Syndrom suchého oka může způsobit rozmazané vidění, které se zlepší promnutím oka či po aplikaci lubrikancií. Dále malé glaukomové 


\section{| MEZIOBOROVÉ PŘEHLEDY}

\section{AMAUROSIS FUGAX}

záchvaty, hrozící okluze centrální retinální

vény - vény bývají tortuózní, dilatované.

Retinální migréna - diagnóza bývá per exclusionem. Bývá jednostranná, s přechodnou poruchou zraku 10-20 minut. Príčinou přechodné poruchy zraku bývá vazospazmus a oční hypoperfuze.

Vertebrobazilárníarteriální insuficience přechodné oboustranné zamlžení trvající od několika vteřin až po několik minut. Vizuální příznaky mohou být doprovázeny ataxií, vertigem, dysartrií či dysfazií a hemiparézou či výpady vnímání z jedné strany. Náhlé pády v anamnéze.

Kolísání glykemie u dekompenzovaného diabetu.

Antifosfolipidový syndrom může způsobit amaurosis fugax. Důležitá je osobní a rodinná anamnéza (předchozí potraty, vyrážka, falešně pozitivní test na syfilis, rodinná anamnéza trombózy) $(1,2,3)$.

\section{Terapie}

Léčba amaurosis fugax závisí na její príčině. Cílem léčby je prevence cévní mozkové príhody.

Internista kompenzuje hypertenzi, diabetes či/a hyperlipidemii. Doporučuje se omezit, prestat kourit.

\section{LITERATURA}

1. Otradovec J. Klinická neurooftalmologie. 1. vyd. Praha: Grada a.S., 2003: 504.

2. Kolektiv autorů. Diagnostika a léčba očních chorob v praxi. The Wills eye manual. Praha: Triton 2004: 155-159.

3. Gowers W. Amaurosis Fugax and Not So Fugax - Vascular Disorders of the Eye. www.us.elsevierhealth. com/../9780750672894.pdf.
Antikoagulační léky jsou v první linii léčby u pacientů s ischemickou amaurosis fugax. Pokud jsou postiženy karotidy či onemocnění srdce, doporučuje se podání acylpyrinu 325 mg/den per os. Nicméně agresivní terapie (antikoagulační terapie, statiny, odvykání kouření) zabraňuje ve srovnání s angioplastikou a stentem výskytu cévní mozkové príhody, a to jak v krátkodobém i dlouhodobém horizontu. Klopidogrel, který inhibuje krevní destičky, je o něco účinnější při prevenci opakující se mrtvice než acylpyrin (2). Dvě velké randomizované studie, Second European Stroke Prevention Study (ESP-2) a Australasian Stroke Prevention European Reverzibil Ischemie Trial (ESPRIT), naznačují, že nízké dávky acylpyrinu v kombinaci s prodlouženým uvolňováním dipyridamolu mohou být účinnější než samotný acylpyrin v sekundární prevenci cévní mozkové príhody. Kardiochirurg zvažuje endarterektomii u stenózy karotid větší než $70 \%$. Pokud jsou srdce i karotidy v normě, zvažujeme vazospastickou etiologii (2). Byly provedeny randomizované studie chirurgické léčby (North American Symptomatic Carotid Endarterectomy Trial, European Carotid

4. Bacigulapi M- Amaurosis Fugax: Clinical Comparison, The Internet Journal of Allied Health Sciences and Practice, 2006; 4(2): http://ijahsp.nova.edu.

5. Tatham AJ. Transient Loss of Vision, http://emedicine.medscape.com/article/1435495-overview.

6. Rubin MN, Barrett KM, Brott TG, Meschia JF. Asymptomatic carotid stenosis: What we can learn from the next ge-
Surgery Trial), které prokázaly význam karotické endarterektomie v sekundární prevenci cévní mozkové príhody u pacientů s cerebrovaskulárními príhodami se stenózou karotid 50-99\% (6). Načasování endarterektomie u symptomatické stenózy vnitřní krkavice zůstává kontroverzní záležitostí. Nedávné údaje neukázaly zvýšené riziko, a to zejména v časném období po nástupu príznaků. V této studii byl zkoumán výsledek endarterektomie karotid v hyperakutní fázi. Celkem bylo zahrnuto 761 symptomatických pacientů $(40,1 \%$ s tranzitorní ischemickou atakou, 21,3\% s amaurosis fugax a 38,6\% s ischemickou cévní mozkovou příhodou). Výsledky ukázaly, že velmi naléhavé operace u symptomatických pacientů mohou být prováděny bez zvýšeného rizika (7).

\section{Závěr}

Amaurosis fugax je přechodná ztráta zraku, která trvá několik minut, výjimkou není ani 1 až 2 hodiny. Nezbytná je pečlivá anamnéza. Etiologie bývá rozmanitá. Nutná je spolupráce oftalmologa, neurologa a internisty. Léčba amaurosis fugax závisí na príčině. Cílem léčby je prevence cévní mozkové př́hody.

neration of randomized clinical trials. JRSM Cardiovasc Dis. 2014: Apr 8; 3.

7. Rantner B, Schmidauer C, Knoflach M, Fraedrich G Very urgent carotid endarterectomy does not increase the procedural risk. Eur J Vasc Endovasc Surg., 2015; 49(2): 129-136. Epub 2014 Oct 27. 